Journal of Clinical Investigation

Vol. 46, No. 3, 1967

\title{
Nature of the Renal Concentrating Defect in Sickle Cell Disease *
}

\author{
Fred E. Hatch, $\dagger$ James W. Culbertson, and Lemuel W. Diggs with the \\ technical assistance of James Gibb Johnson, DWight R. Wade, JR., \\ and Thomas E. Ainsworth \\ (From the Renal Metabolic Laboratory and the Sickle Cell Center, Department of Medicine, \\ College of Medicine, University of Tennessee and City of Memphis Hospitals, \\ Memphis, Tenn.)
}

Summary. Free water reabsorption $\left(\mathrm{T}^{\mathrm{c}}{ }_{\mathrm{H}_{2} \mathrm{O}}\right)$ measured during $10 \%$ mannitol diuresis and subsequently during $3 \%$ saline diuresis was compared in patients with sickle cell anemia and in normal subjects. During mannitol infusion, $\mathrm{T}^{\mathrm{c}} \mathrm{H}_{2} \mathrm{O}$ progressively rose with increasing osmolar clearance $\left(\mathrm{C}_{\mathrm{osm}}\right)$ and reached a maximal level in both groups studied. During hypertonic saline diuresis, $\mathrm{T}^{\mathrm{c}} \mathrm{H}_{2} \mathrm{O}$ progressively rose in the normal subjects and exceeded the maximal levels attained during mannitol diuresis, with no evidence of a maximal $\mathrm{T}^{\mathrm{c}} \mathrm{H}_{2} \mathrm{O}$ level appearing. In contrast, none of the saline curves significantly exceeded the mannitol curves in the sickle cell patients but tended to parallel the mannitol curves at comparable rates of solute clearance.

Since $\mathrm{T}^{\mathrm{c}} \mathrm{H}_{2} \mathrm{O}$ is an index of both solute (sodium) transport from the loop of Henle and solute accumulation in the hypertonic medullary interstitium, tubular sodium handling was examined in both sickle cell patients and control subjects alike. No difference in the tubular transport of sodium could be demonstrated either under conditions of sodium loading or under conditions in which the tubular sodium load was low (water diuresis).

These data support the conclusion that the defect in urinary concentration in sickle cell patients is caused by a limitation in maintaining a high concentration of solute in the medullary interstitium, thus limiting the rate of $\mathrm{T}^{\mathrm{c}}{ }_{\mathrm{H}_{2} \mathrm{O}}$ from the collecting duct.

\section{Introduction}

Understanding of the pathogenesis of sickle cell anemia has advanced rapidly in recent years with the development of hemoglobin electrophoresis and the identification of the genetic abnormality responsible for this disease. New knowledge concerning the sickling phenomenon and the

\footnotetext{
* Submitted for publication July 6, 1965; accepted November 10, 1966.

This investigation was supported by research grants HE 07856, HE 07275, and HE 05684 from the National Institutes of Health and by a grant from the Tennessee Heart Association.

† Address requests for reprints to Dr. Fred E. Hatch, University of Tennessee, College of Medicine, Dobbs Medical Research Institute, 951 Court Ave., Memphis, Tenn. 38103.
}

vagaries of the affected erythrocyte has paved the way for a better correlation of the protean clinical manifestations frequently observed.

The renal involvement in sickle cell anemia has interested investigators for a number of years because of the almost universal presence of a defect in urinary concentration, often without evidence of additional renal functional impairment. Furthermore, despite the inability to attain a maximally concentrated urine, $\mathrm{T}_{\mathrm{H}_{2} \mathrm{O}}$ as measured during mannitol diuresis has been reported to be normal $(1,2)$.

Although pathological evidence of capillary blockage, vascular congestion, medullary scarring, and tubular damage has been observed (3-5), these morphologic changes are not uniformly pres- 
ent in kidneys of sickle cell patients. Moreover, the hyposthenuria in these patients is present almost from birth and persists throughout the life of the individual (6). A correlation between progression of the concentrating defect and advancing age has been noted (6), as well as the slow decline in renal function after the third decade of life, when all clearance values tend to become significantly diminished (7). Continuing vascular damage in the kidney probably plays an important role in the early decline of renal function, as well as in the more advanced changes seen in those patients manifesting evidence of overt renal disease [proteinuria $(8)$, hematuria $(9,10)$, or papillary necrosis (4)]. However, this does not necessarily implicate vascular damage as the etiologic agent in the mechanism of the concentrating defect in children and young adults, which is consistently present despite otherwise normal renal function.

HB AA

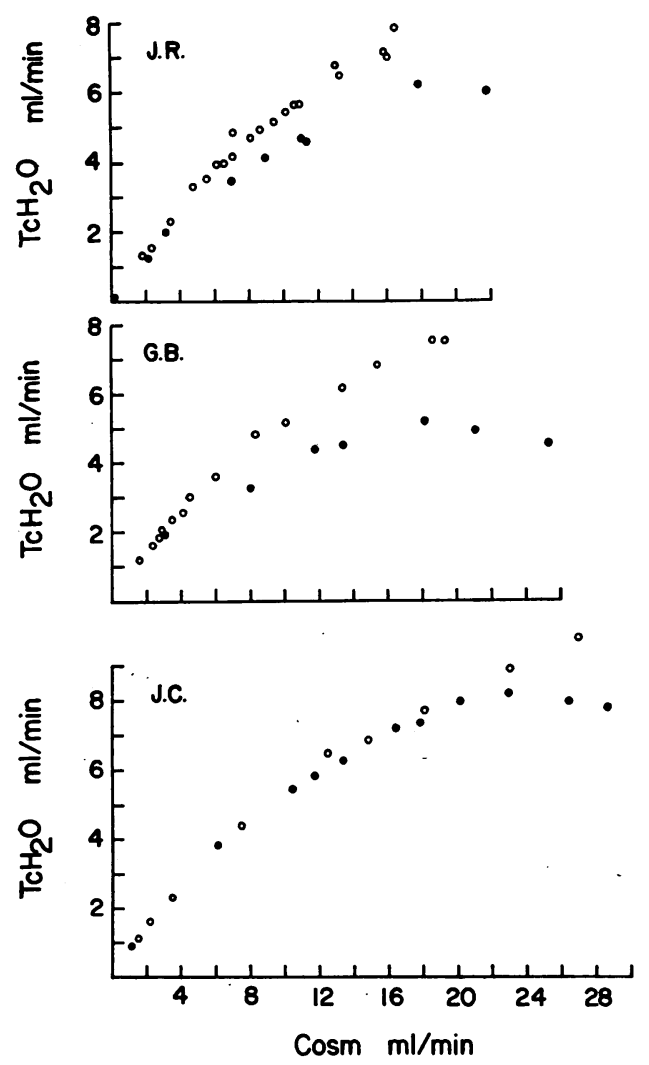

The present studies were designed to investigate the nature of the concentrating defect in sickle cell anemia. A comparison of $\mathrm{T}^{\mathbf{c}} \mathrm{H}_{2} \mathrm{O}$ was made in patients with sickle cell anemia and in normal subjects during both mannitol and hypertonic saline diuresis. Whereas similar $\mathrm{T}^{\mathbf{c}}{ }_{\mathrm{H}_{2} \mathrm{O}}$ curves were obtained during mannitol diuresis, hypertonic saline diuresis revealed marked differences in the capacity for free water reabsorption in the two groups studied as saline loading was progressively increased. Since $\mathrm{T}^{\mathrm{C}} \mathrm{H}_{2} \mathrm{O}$ is a reflection of the rate of tubular sodium transport into the medullary interstitium, tubular sodium handling subsequently was examined under conditions of both high and low sodium loads.

\section{Methods}

Fifty-eight acute experiments were performed in 13 patients with sickle cell anemia (SS hemoglobin) and 14
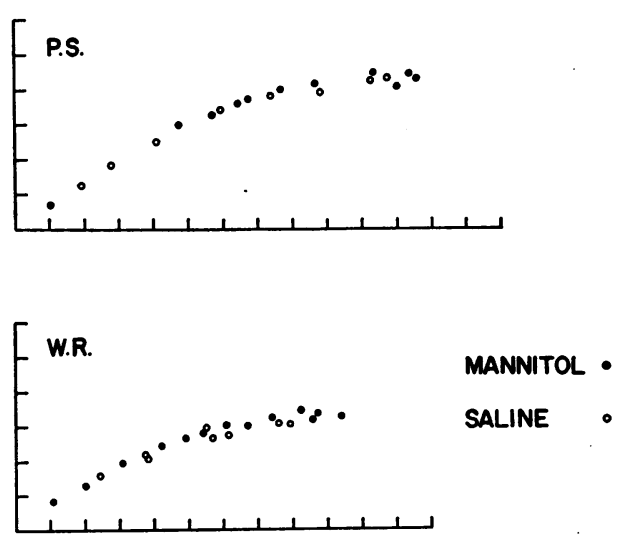

Fig. 1. Characteristic $\mathrm{T}^{\mathbf{c}}{ }_{\mathrm{H}_{2} \mathrm{O}}$ : $\mathrm{C}_{\mathrm{osm}}$ (Free Water Reabsorption: osmolar Clearance) CURVES MEASURING FREE WATER REABSORPTION DURING 10\% MANNITOL AND 3\% SALINE DIURESIS. Note the divergence in the mannitol and the saline $\mathrm{T}^{\mathrm{c}}{ }_{\mathrm{H}_{2} \mathrm{O}}$ curves in the normal subjects with increasing Cosm when compared to the "parallel" curves in the sickle cell patients. 
TABLE I

Protocol of representative experiments during mannitol and saline diuresis*

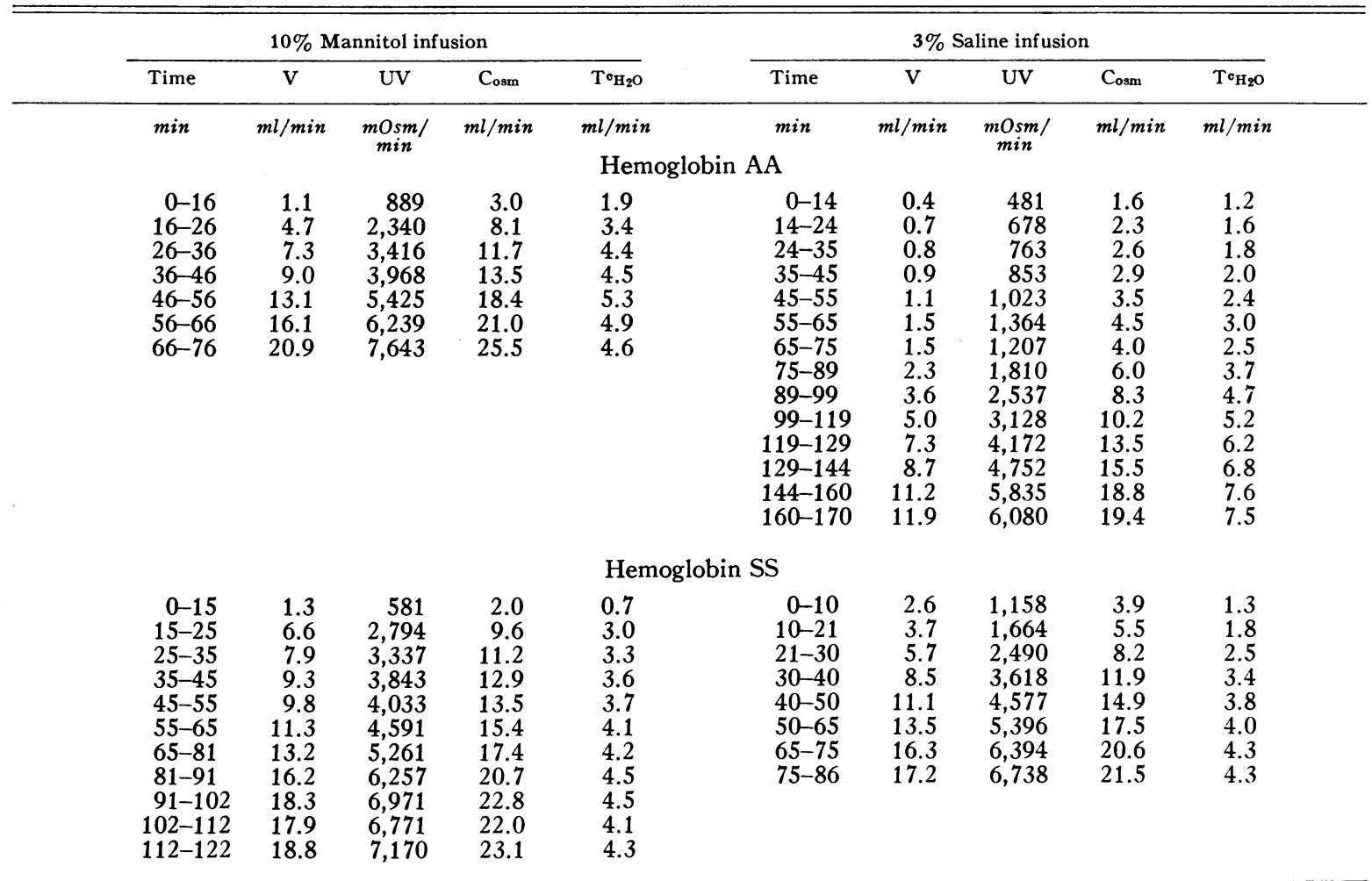

* Abbreviations: $\mathrm{V}=$ urine flow $\mathrm{UV}=$ solute excretion; $\mathrm{C}_{\mathrm{osm}}=$ osmolar clearance; $\mathrm{Tc}_{\mathrm{H}_{2} \mathrm{O}}=$ free water reabsorption. All values corrected to $1.73 \mathrm{~m}^{2} \mathrm{BSA}$.

normal subjects in the Renal Metabolic Laboratory and the Sickle Cell Center at the University of Tennessee. There were 13 female and 14 male subjects ranging from 14 to 26 years of age. Glomerular filtration rates were assessed simultaneously in all subjects during each experiment by measuring plasma inulin clearance. After appropriate priming doses, a continuous infusion of inulin was administered at a constant rate to maintain adequate blood levels. No evidence of renal disease was present except the concentrating defect, which was found in all of the sickle cell group.

$T^{c}{ }_{\mathrm{B}_{2} \mathrm{O}}$ studies. All food and fluids were withheld for 12 to 15 hours before each test, and $0.5 \mathrm{U}$ vasopressin was administered intramuscularly 30 minutes before the study. A solution containing $10 \%$ mannitol in $0.9 \%$ saline and aqueous vasopressin in a dosage of $30 \mathrm{mU}$ per $\mathrm{kg}$ per hour was infused at a constant rate of 8 to $12 \mathrm{ml}$ per minute with a Sigamotor infusion pump. Urine specimens were collected from the bladder at approximately 10-minute intervals through an indwelling catheter, and venous blood samples were withdrawn from the forearm through an indwelling needle at the midpoint of each collection period. The infusion was continued until a definite maximal $\mathrm{T}^{\mathrm{c}}{ }_{\mathrm{H}_{2} \mathrm{O}}$ level $\left(\mathrm{T}^{\mathrm{c}} \mathrm{m}_{\mathrm{H}_{2} \mathrm{O}}\right)$ was established.

In subsequent experiments a similar test was performed with $3 \%$ saline as the osmotic diuretic. The in- fusion was administered at a rate of 8 to $14 \mathrm{ml}$ per minute until the $\mathrm{T}_{\mathrm{H}_{2} \mathrm{O}}$ either reached a maximal level or surpassed that obtained during mannitol diuresis at comparable solute clearances. At least 2 days elapsed between consecutive studies on any individual subject.

Sodium transport studies. Subjects were studied under conditions of sodium loading after 15 hours of dehydration. After the priming dose of inulin had been administered, the sustaining solution containing inulin in $0.9 \%$ saline and $10 \%$ mannitol (10 studies) or in $0.9 \%$ saline alone ( 5 studies) was infused at a constant rate of $10 \mathrm{ml}$ per minute. Urine specimens were collected every 10 to 20 minutes, and blood samples were withdrawn at the midpoint of each collection period.

Additional experiments were performed under conditions of low tubular sodium loads (water diuresis). Patients were hydrated by oral ingestion of water at the beginning of the study, and water was ingested throughout the experiment in amounts sufficient to maintain increasing urine flow rates. Urine and blood samples were collected as outlined above. Each experiment was continued until the urinary osmolality attained a minimal value and until solute-free water clearance $\left(\mathrm{C}_{\mathbf{H}} \mathbf{O}\right)$ of at least $13 \mathrm{ml}$ per minute was established.

Chemical methods. Blood and urinary osmolalities were determined by the freezing point depression method 
TABLE II

Summary of free water reabsorption studies in normal subjects and sickle cell patients during mannitol and saline diuresis*

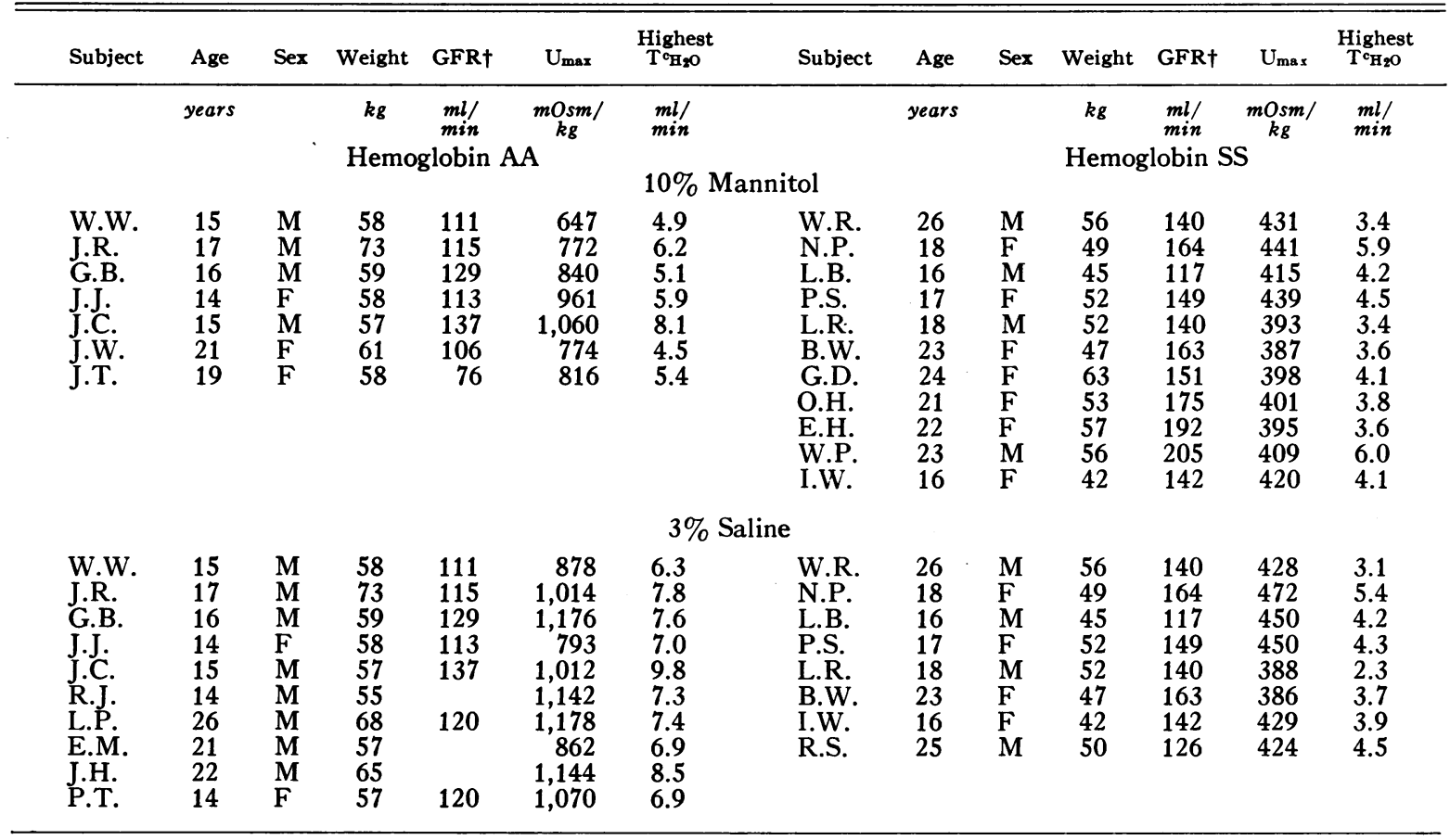

* Abbreviations as in Table I. GFR = glomerular filtration rate; $U_{\max }=$ maximal urinary osmolality.

t Corrected to $1.73 \mathrm{~m}^{2} \mathrm{BSA}$.

TABLE III

Effect of sodium loading on tubular sodium transport in normal subjects and sickle cell patients*

\begin{tabular}{|c|c|c|c|c|c|c|}
\hline Time & $\mathrm{Vt}$ & GFR† & $\mathrm{FN}_{\mathrm{N}} \dagger$ & $\mathrm{UNaV}_{\mathbf{N}}$ & TNat & $\mathrm{TN}_{\mathrm{a}} / \mathrm{FN}_{\mathrm{a}}$ \\
\hline $\min$ & $m l / m i n$ & $m l / \min$ & $\begin{array}{l}m E q / \min \\
\text { loglobin AA }\end{array}$ & $m E q / \min$ & $m E q / \min$ & $\%$ \\
\hline $\begin{array}{c}0-20 \\
20-30 \\
30-40 \\
40-50 \\
50-60 \\
60-70 \\
70-80 \\
80-90 \\
90-100 \\
100-110\end{array}$ & $\begin{array}{r}2.4 \\
5.0 \\
5.9 \\
7.0 \\
9.2 \\
10.5 \\
12.2 \\
14.8 \\
18.3 \\
20.8\end{array}$ & $\begin{array}{l}175 \\
136 \\
125 \\
136 \\
142 \\
137 \\
128 \\
134 \\
140 \\
133\end{array}$ & $\begin{array}{l}23.57 \\
18.24 \\
16.25 \\
17.69 \\
18.28 \\
17.49 \\
16.08 \\
17.02 \\
17.81 \\
16.65\end{array}$ & $\begin{array}{l}0.25 \\
0.38 \\
0.45 \\
0.54 \\
0.71 \\
0.84 \\
0.99 \\
1.23 \\
1.59 \\
1.90\end{array}$ & $\begin{array}{l}23.32 \\
17.86 \\
15.80 \\
17.15 \\
17.57 \\
16.65 \\
15.09 \\
15.79 \\
16.22 \\
14.75\end{array}$ & $\begin{array}{l}98.9 \\
97.9 \\
97.2 \\
96.9 \\
96.1 \\
95.2 \\
93.8 \\
92.8 \\
91.1 \\
88.6\end{array}$ \\
\hline $\begin{array}{c}0-41 \\
41-61 \\
61-71 \\
71-81 \\
81-91 \\
91-101 \\
101-111 \\
111-121 \\
121-131 \\
131-141\end{array}$ & $\begin{array}{r}2.4 \\
5.3 \\
8.8 \\
11.3 \\
12.8 \\
15.2 \\
16.8 \\
19.0 \\
19.8 \\
20.6\end{array}$ & $\begin{array}{l}217 \\
166 \\
169 \\
168 \\
184 \\
168 \\
174 \\
166 \\
165\end{array}$ & $\begin{array}{l}\text { loglobin SS } \\
28.90 \\
22.02 \\
21.97 \\
22.08 \\
24.01 \\
21.77 \\
22.23 \\
21.25 \\
21.34\end{array}$ & $\begin{array}{l}0.34 \\
0.52 \\
0.70 \\
0.84 \\
0.94 \\
1.10 \\
1.28 \\
1.43 \\
1.46 \\
1.50\end{array}$ & $\begin{array}{l}28.38 \\
21.32 \\
21.13 \\
21.14 \\
22.91 \\
20.49 \\
20.80 \\
19.79 \\
19.84\end{array}$ & $\begin{array}{l}98.2 \\
96.8 \\
96.1 \\
95.7 \\
95.5 \\
94.1 \\
93.6 \\
93.1 \\
93.0\end{array}$ \\
\hline
\end{tabular}

* Abbreviations as in preceding Tables. $\mathrm{F}_{\mathrm{Na}}=$ filtered sodium load; $\mathrm{U}_{\mathrm{Na}} \mathrm{V}=$ urinary sodium excretion; $\mathrm{T}_{\mathrm{Na}}=$ tubular sodium reabsorption; $\mathrm{T}_{\mathrm{Na}} / \mathrm{F}_{\mathrm{Na}}=$ fraction of the filtered load of sodium reabsorbed. All experiments contained $10 \%$ mannitol to permit observations of tubular sodium transport at varying rates of solute excretion. Since mannitol may limit tubular sodium reabsorption, additional experiments with infusion of $0.9 \%$ saline alone were performed, which revealed no difference in sodium transport in the two groups studied.

$\dagger$ Corrected to $1.73 \mathrm{~m}^{2} \mathrm{BSA}$. 
by use of an Advanced osmometer. Inulin was measured in plasma and urine by the method of Walser, Davidson, and Orloff (11). Serum and urinary sodium and potassium were measured on an Instrumentation Laboratories flame photometer. $\mathrm{C}_{\text {osm } m}$ was calculated as $\mathrm{U}_{\text {osm } \mathrm{V}} \mathrm{V}$ / $\mathrm{P}_{\text {osm }}$, where $\mathrm{U}_{\text {osm }}=$ osmolality of urine (milliosmoles per kilogram), $\mathrm{P}_{\mathrm{osm}}=$ osmolality of serum (milliosmoles per kilogram), and $\mathrm{V} \doteq$ urine flow (milliliters per minute). $\mathrm{T}^{\mathbf{c}_{\mathrm{H}_{2} \mathrm{O}}}$ was calculated as $\mathrm{C}_{\mathrm{osm}_{\mathrm{m}}}-\mathrm{V}$. $\mathrm{C}_{\mathrm{H}_{2} \mathrm{O}}$ was calculated as $\mathrm{V}-\mathrm{C}_{\mathrm{osm}}$. $\mathrm{T}^{\mathrm{c}} \mathrm{m}_{\mathrm{H}_{2} \mathrm{O}}$ was calculated as the mean of the highest $\mathrm{T}^{\mathrm{c}}{ }_{\mathrm{H}_{2} \mathrm{O}}$ values attained after reaching a constant level despite additional increases in $\mathrm{C}_{\text {osm }}$. Standard statistical techniques were used throughout (12).

\section{Results}

$T^{c_{H_{2} \mathrm{O}}}$ studies. The characteristic $\mathrm{T}_{\mathrm{H}_{2} \mathrm{O}}: \mathrm{C}_{\mathrm{osm}}$ curves during $10 \%$ mannitol and $3 \%$ saline diuresis from studies in each group of patients are shown in Figure 1. The protocols of representative experiments are outlined in Table I, and the results of all such studies are summarized in Table II. During mannitol diuresis in both normal subjects and in sickle cell patients a progressive rise in $\mathrm{T}^{\mathrm{c}} \mathrm{H}_{2} \mathrm{O}$ with increasing $\mathrm{C}_{\mathrm{osm}}$ was observed. $\mathrm{T}^{\mathrm{c}} \mathrm{H}_{2} \mathrm{O}$ approached a maximal level $\left(\mathrm{T}^{\mathrm{c}} \mathrm{m}_{\mathrm{H}_{2} \mathrm{O}}\right)$ as $\mathrm{C}_{\text {osm }}$ increased to 14 to $16 \mathrm{ml}$ per minute in the control group and 14 to $18 \mathrm{ml}$ per minute in the study group, and either remained constant or slightly declined with additional increases in $\mathrm{C}_{\mathrm{osm}}$.

During 3\% saline diuresis in the normal group, $\mathrm{T}^{\mathrm{H}_{2} \mathrm{O}}{ }_{\mathrm{O}} \mathrm{C}_{\mathrm{osm}}$ curves initially rose in a similar manner to the mannitol curves but exceeded the maximal levels attained during mannitol diuresis as $\mathrm{C}_{\text {osm }}$ increased from 13 to $20 \mathrm{ml}$ per minute. At higher rates of $\mathrm{C}_{\mathrm{osm}}$, the saline $\mathrm{T}_{\mathbf{H}_{2} \mathrm{O}}$ : $\mathrm{C}_{\mathrm{osm}}$ curves continued to rise above the mannitol curves with no evidence of a maximal $\mathrm{T}^{\mathrm{c}}{ }_{\mathrm{H}_{2} \mathrm{O}}$ level appearing. The saline curves in the patients with SS hemoglobin, however, closely followed their mannitol curves, both in configuration and maximal $\mathrm{T}^{\mathbf{c}} \mathrm{H}_{2} \mathrm{O}$ levels. None of the saline curves exceeded their mannitol curves significantly, even at $\mathrm{C}_{\text {osm }}$ values as high as $32 \mathrm{ml}$ per minute, but tended to parallel

TABLE IV

Summary of individual studies on tubular sodium transport under conditions of sodium loading and water diuresis*

\begin{tabular}{|c|c|c|c|c|c|c|c|c|c|}
\hline Subject & $\mathrm{F}_{\mathrm{Na}} \dagger$ & $\begin{array}{l}\text { Slope } \\
\text { UNaV } \\
\text { vs. V† }\end{array}$ & $T_{N_{B}} \dagger$ & $\begin{array}{l}\mathrm{TN}_{\mathrm{a}} / \\
\mathrm{FNa}_{\mathrm{a}} \uparrow\end{array}$ & Subject & $\mathrm{FNa}_{\mathrm{N}} \dagger$ & $\begin{array}{l}\text { Slope } \\
\mathrm{UNaV}_{\mathrm{a}} \\
\text { vs. V† }\end{array}$ & TNat & $\mathrm{TNa}_{\mathrm{a}} / \mathrm{FNa}_{\mathrm{a}} \dagger$ \\
\hline & $m E q / \min$ & Hemog & $\begin{array}{l}m E q / \min \\
\operatorname{jin} \mathrm{AA}\end{array}$ & $\%$ & & $m E q / \min$ & Hemc & $\begin{array}{l}m E q / \min \\
\operatorname{jin} \mathrm{SS}\end{array}$ & $\%$ \\
\hline \multicolumn{10}{|c|}{ Sodium loading } \\
\hline $\begin{array}{l}\text { J.R. } \\
\text { P.T. } \\
\text { J.J. } \\
\text { J.C. }\end{array}$ & $\begin{array}{l}14.00 \\
12.00 \\
12.96 \\
16.89\end{array}$ & $\begin{array}{l}65.13 \\
66.90 \\
58.30 \\
88.37\end{array}$ & $\begin{array}{l}13.12 \\
10.73 \\
12.08 \\
15.46\end{array}$ & $\begin{array}{l}93.8 \\
89.4 \\
93.2 \\
91.6\end{array}$ & $\begin{array}{l}\text { W.P. } \\
\text { L.R. } \\
\text { B.W. } \\
\text { D.H. } \\
\text { G.D. } \\
\text { N.P. }\end{array}$ & $\begin{array}{l}26.35 \\
16.71 \\
17.78 \\
22.09 \\
18.94 \\
25.27\end{array}$ & $\begin{array}{l}69.02 \\
83.49 \\
93.22 \\
65.69 \\
56.46 \\
68.12\end{array}$ & $\begin{array}{l}24.80 \\
15.06 \\
15.27 \\
20.87 \\
18.06 \\
23.75\end{array}$ & $\begin{array}{l}94.1 \\
90.1 \\
85.8 \\
94.5 \\
95.3 \\
94.0\end{array}$ \\
\hline $\begin{array}{l}\text { Mean } \\
\text { SD } \\
\text { p\$ }\end{array}$ & $\begin{array}{r}13.96 \\
2.11\end{array}$ & $\begin{array}{l}69.68 \\
13.00\end{array}$ & $\begin{array}{r}12.85 \\
2.00\end{array}$ & $\begin{array}{r}92.0 \\
1.9\end{array}$ & & $\begin{array}{r}21.19 \\
4.02 \\
<0.05\end{array}$ & $\begin{array}{r}72.67 \\
13.31 \\
>0.50\end{array}$ & $\begin{array}{r}19.64 \\
4.19 \\
<0.05\end{array}$ & $\begin{array}{c}92.3 \\
3.7 \\
>0.50\end{array}$ \\
\hline \multicolumn{10}{|c|}{ Water diuresis } \\
\hline $\begin{array}{l}\text { J.R. } \\
\text { P.T. } \\
\text { G.O. } \\
\text { J.J. } \\
\text { J.H. }\end{array}$ & $\begin{array}{l}16.07 \\
16.55 \\
17.09 \\
18.79 \\
19.54\end{array}$ & $\begin{array}{r}7.81 \\
5.64 \\
11.24 \\
9.39 \\
10.97\end{array}$ & $\begin{array}{l}15.78 \\
16.15 \\
16.72 \\
18.28 \\
19.40\end{array}$ & $\begin{array}{l}98.2 \\
97.6 \\
97.8 \\
97.3 \\
99.3\end{array}$ & $\begin{array}{l}\text { W.P. } \\
\text { L.R. } \\
\text { B.W. } \\
\text { O.H. } \\
\text { G.D. } \\
\text { N.P. }\end{array}$ & $\begin{array}{l}31.31 \\
18.04 \\
22.48 \\
24.96 \\
23.34 \\
21.96\end{array}$ & $\begin{array}{r}18.35 \\
13.43 \\
27.43 \\
9.58 \\
14.13 \\
11.02\end{array}$ & $\begin{array}{l}30.54 \\
17.41 \\
21.60 \\
24.54 \\
22.71 \\
21.56\end{array}$ & $\begin{array}{l}97.5 \\
96.5 \\
96.1 \\
98.3 \\
97.6 \\
98.2\end{array}$ \\
\hline $\begin{array}{l}\text { Mean } \\
\text { SD } \\
\text { p\$ }\end{array}$ & $\begin{array}{r}17.61 \\
1.49\end{array}$ & $\begin{array}{l}9.01 \\
2.33\end{array}$ & $\begin{array}{r}17.27 \\
1.53\end{array}$ & $\begin{array}{r}98.0 \\
0.8\end{array}$ & & $\begin{array}{r}23.68 \\
4.39 \\
<0.05\end{array}$ & $\begin{array}{r}15.66 \\
6.36 \\
>0.05\end{array}$ & $\begin{array}{r}23.06 \\
4.35 \\
<0.05\end{array}$ & $\begin{array}{c}97.4 \\
0.9 \\
>0.10\end{array}$ \\
\hline
\end{tabular}

* Abbreviations as in preceding Tables. minute.

† These columns represent the mean values of collection periods from each individual study when $\mathrm{V}$ exceeds $11 \mathrm{ml}$ per

$\ddagger$ This column shows the calculated slopes of the regression line of $U_{\mathrm{Na}} \mathrm{V}$ vs. $\mathrm{V}$ when the relationship is linear.

$\S$ The p values pertain to the mean values in the control and in the sickle cell groups during 1 )sodium loading and 2) water diuresis. 
NATURE OF THE RENAL CONCENTRATING DEFECT IN SICKLE CELL DISEASE

TABLE V

Effect of water diuresis on tubular sodium transport in normal subjects and sickle cell patients*

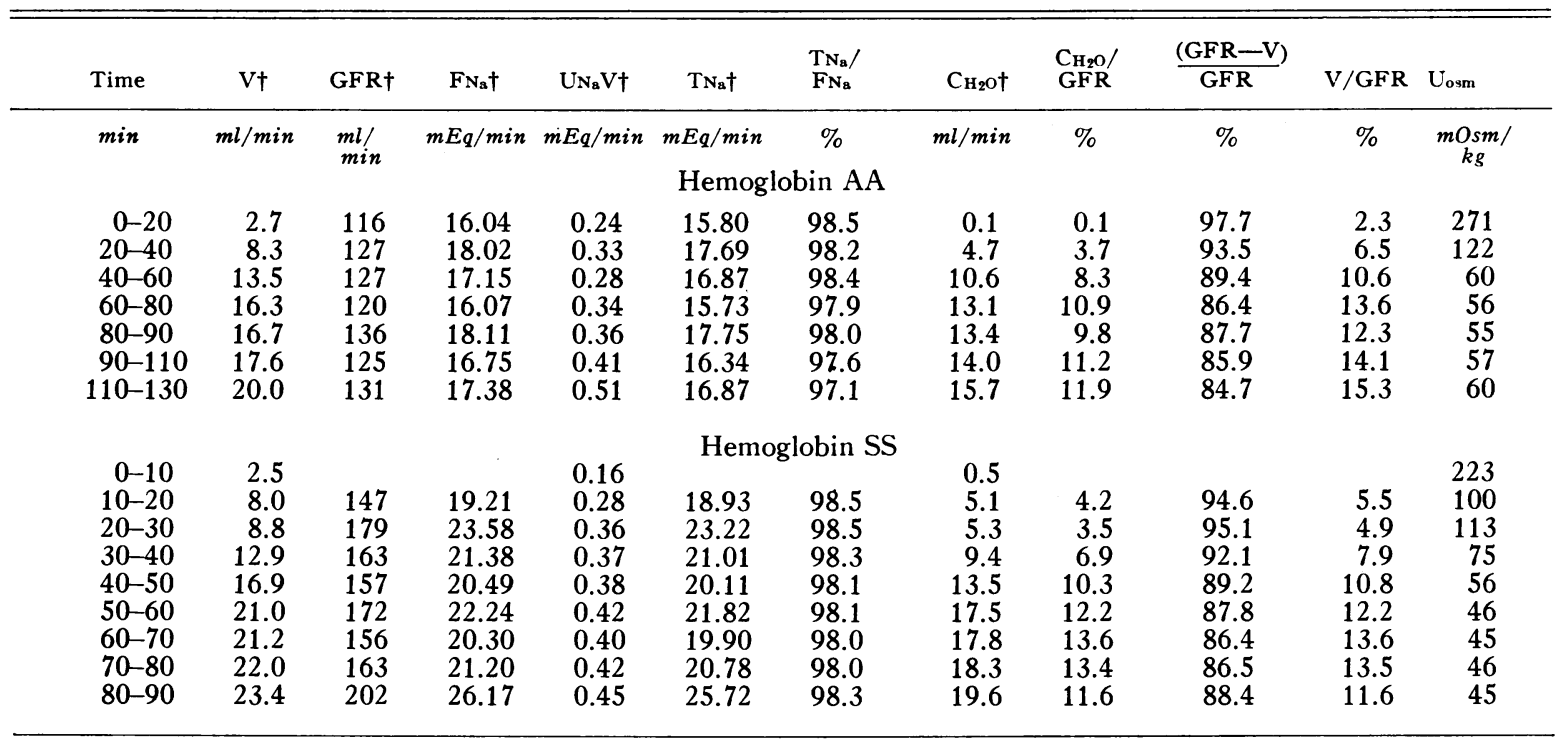

${ }^{*} \mathrm{C}_{\mathrm{H}_{2} \mathrm{O}}=$ free water clearance; $\mathrm{C}_{\mathrm{H}_{2} \mathrm{O}} / \mathrm{GFR}=$ fraction of the filtered sodium reabsorbed in the distal tubule; (GFR $-\mathrm{V}) / \mathrm{GFR}=$ fraction of glomerular filtrate reabsorbed in the proximal tubule; $\mathrm{V} / \mathrm{GFR}=$ fraction of glomerular filtrate excreted into the urine; $\mathrm{U}_{\mathrm{osm}}=$ urinary osmolality. Other abbreviations as in preceding Tables.

† Corrected to $1.73 \mathrm{~m}^{2} \mathrm{BSA}$.

the mannitol curves at comparable rates of solute clearance (Figure 1).

Sodium transport studies. The protocol of representative experiments during sodium loading is shown in Table III. The results of all experiments are summarized in Table IV. The filtered sodium load $\left(\mathrm{F}_{\mathrm{Na}}\right)$ was significantly greater in the sickle cell patients because of the consistently higher glomerular filtration rate (GFR) $(p<$ $0.05)$. As the anticipated rise in urine flow was observed, however, the increased sodium excretion $\left(\mathrm{U}_{\mathrm{Na}} \mathrm{V}\right)$ was approximately equal in the two groups. Because of the greater flow attained by sickle cell patients in some experiments, the slopes of the regression line of $\mathrm{U}_{\mathrm{Na}} \mathrm{V}$ vs. $\mathrm{V}$ were calculated for both groups (Table IV) and were found to be similar $(p>0.50)$. In addition, when the absolute tubular reabsorption of sodium $\left(\mathrm{T}_{\mathrm{Na}}\right)$ was compared, it was consistently increased in the sickle cell patients because of the greater $\mathrm{F}_{\mathrm{Na}}(\mathrm{p}<0.05)$, but when $T_{\mathrm{Na}}$ was factored by $\mathrm{F}_{\mathrm{Na}}$, the fraction of the filtered load of sodium reabsorbed $\left(\mathrm{T}_{\mathrm{Na}} / \mathrm{F}_{\mathrm{Na}}\right)$ did not differ significantly from the controls $(p>$ $0.50)$.

During the course of water diuresis (Tables IV and $\mathrm{V}$ ) the GFR, and consequently $\mathrm{F}_{\mathrm{Na}}$, also were appreciably greater in the sickle cell patients $(\mathrm{p}<$ $0.05)$; whereas, when $\mathrm{U}_{\mathrm{Na}} \mathrm{V}$ and the slopes of $\mathrm{U}_{\mathrm{Na}} \mathrm{V}$ vs. $\mathrm{V}$ were compared, the two groups were observed to be similar $(\mathrm{p}>0.05)$. $\mathrm{T}_{\mathrm{Na}}$ in the study group was invariably higher $(p<0.05)$,

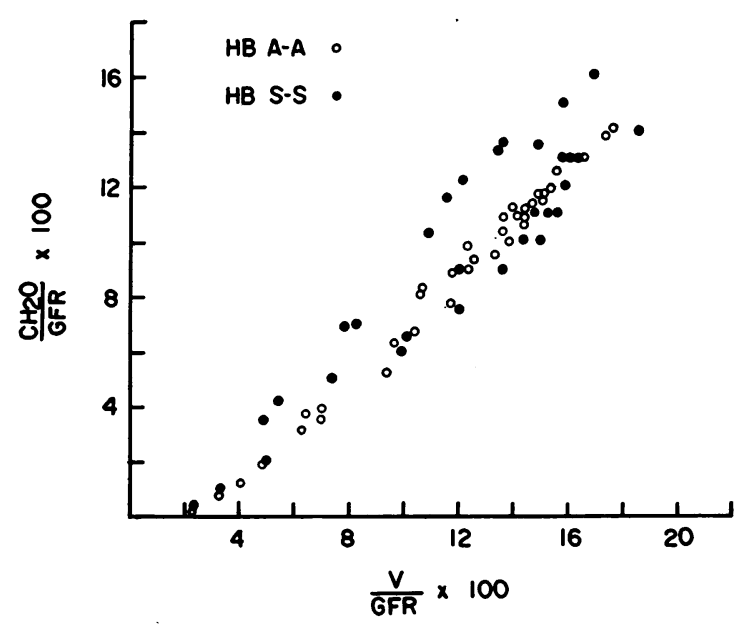

Fig. 2. FraCtional eXCRETION OF FREE WATER ( $\mathrm{C}_{\mathrm{H}_{2} \mathrm{O}}$ / GFR) AT VARYING FRACTIONAL RATES OF URINE FLOW (V/GFR) IN NORMAL SUBJECTS AND SICKLE CELL PATIENTS DURING WATER DIURESIS. GFR = glomerular filtration rate. 
but $\mathrm{T}_{\mathrm{Na}} / \mathrm{F}_{\mathrm{Na}}$ revealed no difference in the fraction of filtered sodium reabsorbed $(p>0.10)$.

The ability to dilute the urine was compared during water diuresis as shown in Table V. Both the fraction of glomerular filtrate reabsorbed in the proximal portions of the nephron [ (GFR - V)/ GFR] and the fraction of glomerular filtrate excreted into the urine $(\mathrm{V} / \mathrm{GFR})$ revealed similar values in sickle cell patients and control subjects. $\mathrm{U}_{\text {osm }}$ fell correspondingly in both groups, whereas $\mathrm{C}_{\mathrm{H}_{2} \mathrm{O}} \mathrm{O}$ progressively rose. The absolute values of $\mathrm{C}_{\mathrm{H}_{2} \mathrm{O}}$ became higher in the sickle cell group, but the fractional excretion of free water $\left(\mathrm{C}_{\mathrm{H}_{2} \mathrm{O}} / \mathrm{GFR}\right)$ was approximately equal. When $\mathrm{C}_{\mathrm{H}_{2} \mathrm{O}} / \mathrm{GFR}$ was plotted vs. V/GFR in order to compare the ability to generate free water at any given flow rate, no significant difference was found (Figure 2).

\section{Discussion}

Maximal free water reabsorption levels during loading with nonreabsorbable solute (mannitol) have been reported to be within normal limits in children with sickle cell anemia $(1,2)$. A normal $\mathrm{T}^{\mathrm{c}} \mathrm{m}_{\mathrm{H}_{2} \mathrm{O}}$ in the presence of a defect in urinary concentration is in contrast with the findings in most renal disease states, in which an inability to concentrate the urine is accompanied by an impairment in free water reabsorption.

During mannitol loading in normal hydropenic subjects increasing rates of $\mathrm{C}_{\mathrm{osm}}$ are associated with a progressive rise in $\mathrm{T}^{\mathrm{c}} \mathrm{H}_{2} \mathrm{O}$ until a maximal $\mathrm{T}^{\mathrm{c}} \mathrm{H}_{2} \mathrm{O}$ is reached that levels off in plateau fashion or slowly declines (13). Since $\mathrm{T}_{\mathrm{H}_{2} \mathrm{O}}$ reflects the passive movement of water from the collecting ducts into the hypertonic medullary interstitium, it is dependent on continuing solute accumulation in the medulla to maintain hypertonicity in the face of increasing water reabsorption. It has been shown that the osmotic effect of mannitol decreases tubular sodium concentration (14), which is thought to impose a limitation on tubular sodium transport from the ascending limb of the loop of Henle into the medulla (15). Accordingly, the collecting duct fluid will approach osmotic equilibrium with the medullary interstitium, resulting in a maximal $\mathrm{T}^{\mathbf{c}}{ }_{\mathrm{H}_{2} \mathrm{O}}$ level.

During hypertonic saline diuresis, on the other hand, $\mathrm{T}_{\mathrm{H}_{2} \mathrm{O}} \mathrm{O}$ normally continues to rise above the maximal level of mannitol diuresis (15). Recent evidence indicates that during hypertonic saline infusion, the reabsorption of sodium along the loop of Henle increases proportionately to sodium load $(16,17)$. Since the sodium concentration in the early distal tubule remains hypotonic, no tubular transfer maximum for sodium in the loop is evident. With increasing rates of sodium reabsorption across the ascending limb, solute accumulation in the medulla is enhanced, thus establishing the conditions necessary for unlimited free water abstraction.

When $\mathrm{T}^{\mathbf{c}_{\mathrm{H}_{2} \mathrm{O}}}$ : $\mathrm{C}_{\mathrm{osm}}$ curves during hypertonic saline diuresis in sickle cell patients are examined, the curves are seen to resemble closely those of mannitol diuresis and to reach maximal $\mathrm{T}^{\mathbf{c}} \mathrm{H}_{2} \mathrm{O}$ levels in similar fashion at corresponding rates of solute clearance. Since $\mathrm{T}^{\mathbf{c}}{ }_{\mathrm{H}_{2} \mathrm{O}}$ is an index of both solute (sodium) transport from the loop of Henle and its accumulation in the hypertonic medullary interstitium, the tubular sodium transport system was examined under conditions of high and low sodium loads.

During sodium loading, when the tubular sodium concentration was high, the filtered load of sodium in the sickle cell patients exceeded that in normal subjects (Tables III and IV), reflecting the higher GFR in the former group. Levitt, Hauser, Levy, and Polimeros, however, observed that lowering the GFR decreases sodium excretion to the same degree in both groups (18). Moreover, the present studies revealed no difference in the rate of sodium excretion, despite the difference in filtered load. Although the tubular reabsorption of sodium was increased in sickle cell patients during sodium loading, no difference in the fraction of the filtered load of sodium reabsorbed by the tubules occurred (Table IV). These observations provide strong evidence that tubular sodium excretion in sickle cell patients is normal during sodium loading. Although a defect in loop sodium transport cannot be excluded completely by these studies, it would be necessary to postulate increased sodium reabsorption in the distal tubule to account for comparable rates of sodium excretion. Such a conclusion does not seem necessary or warranted, since $\mathrm{T}^{\mathrm{c}} \mathrm{m}_{\mathrm{H}_{2} \mathrm{O}}$ is usually nor$\mathrm{mal}$ in young sickle cell patients during mannitol diuresis, implying no difference in sodium reabsorption in the loop of Henle.

When the sodium transport system was exam- 
ined under conditions in which the tubular sodium load was low (water diuresis), similar results were obtained as with sodium loading (Tables IV and V). Despite an increase in filtered load in the sickle cell patients, the rate of sodium excretion revealed no significant difference. Similarly, the tubular reabsorption of sodium was greater in the study group, but the difference in the fraction of the filtered load of sodium reabsorbed was negligible. $U_{o s m}$ fell to correspondingly low levels in all patients studied as water diuresis progressed, indicating a normal ability to dilute the urine in sickle cell anemia, as reported previously $(19,20)$. Comparison in the two groups of both the percentage of glomerular filtrate reabsorbed in the proximal portions of the nephron and the percentage of glomerular filtrate excreted into the urine revealed no difference in the pattern of water excretion during water diuresis $\left(\right.$ Table V). ${ }^{1}$

Additional evidence for normal tubular sodium transport was obtained when $\mathrm{C}_{\mathrm{H}_{2} \mathrm{O}}$ was examined. Since $\mathrm{C}_{\mathrm{H}_{2} \mathrm{O}}$ is dependent on active sodium transport from the ascending limb of Henle's loop and distal tubule without an equivalent movement of water (23), it is evident that any defect in sodium transport at these sites would impair $\mathrm{C}_{\mathrm{H}_{2} \mathrm{O}}$. In this regard, $\mathrm{C}_{\mathrm{H}_{2} \mathrm{O}}$ reflects ascending limb and distal sodium transport. Similarly, $\mathrm{C}_{\mathrm{H}_{2} \mathrm{O}} / \mathrm{GFR}$ directly expresses the fractional excretion of free water and indirectly reflects the fraction of the filtered sodium load reabsorbed in the distal tubules. When these parameters were compared, absolute values of $\mathrm{C}_{\mathrm{H}_{2} \mathrm{O}}$ were seen to be greater in the sickle cell patients because of the higher rate of $\mathrm{V}$, but $\mathrm{C}_{\mathrm{H}_{2} \mathrm{O}} / \mathrm{GFR}$ was quite similar to that of the control subjects (Table V).

To compare further free water generation we plotted $\mathrm{C}_{\mathrm{H}_{2} \mathrm{O}}$ /GFR vs. V/GFR, since $\mathrm{V}$ more accurately reflects the rate of delivery of glomerular filtrate to diluting sites than $\mathrm{C}_{\text {osm }}$ during water diuresis, when the distal tubule and collecting duct are relatively impermeable to water. The re-

\footnotetext{
1 Even though some back diffusion of water from the collecting duct is known to occur during water diuresis despite lack of antidiuretic hormone $(21,22)$, the relatively water impermeable distal tubular segments minimize the effect of medullary solute accumulation on the pattern of water excretion. Any alteration from the normal under these conditions would more likely reflect abnormal sodium transport.
}

sults demonstrated that $\mathrm{C}_{\mathrm{H}_{2} \mathrm{O}}$ was formed equally at corresponding flow rates in the two groups studied (Figure 2 ).

The renal concentrating defect has been attributed to renal damage due to intravascular sickling, stasis, and vascular occlusion $(1,6)$, which have been seen to occur in the kidney as well as many other organs of the body in sickle cell patients. In support of this concept Perillie and Epstein (24) have demonstrated increased sickling in vitro when erythrocytes containing S-hemoglobin are immersed in hyperosmotic saline solutions, suggesting that the milieu of the renal medulla enhances sickling, which in turn decreases medullary blood flow. No increase in sickling was noted below an osmolality of $600 \mathrm{mOsm}$ per $\mathrm{kg}$, however, with a maximal increase being reached at 600 to $1,000 \mathrm{mOsm}$ per $\mathrm{kg}$. Since patients with SS hemoglobin are seldom able to concentrate their urine $\left(U_{\max }\right)$ over $600 \mathrm{mOsm}$ per $\mathrm{kg}$ even in infancy and rarely over $500 \mathrm{mOsm}$ per $\mathrm{kg}$ beyond the age of 7 years $(6,25)$ (Table II), and since the difference in osmolality between the final urine and the medullary interstitium is small to negligible except in water diuresis (26), it appears that hypertonic concentrations necessary to increase the sickling phenomena are infrequently attained in vivo. Although vascular damage undoubtedly plays an increasingly important role in sickle cell nephropathy with advancing age, it does not seem to explain adequately the renal concentrating defect that is present almost from birth, often without accompanying demonstrable vascular changes.

The medullary interstitium maintains its hypertonicity to plasma through a combination of loop solute (primarily sodium) transport into the medulla and the action of the vasa recta acting as countercurrent diffusion exchangers to minimize solute loss from the medulla. In addition, the removal of water by the vasa recta is essential if hypertonicity is to be maintained in the face of increasing water reabsorption from the descending limb of the loop of Henle and the collecting ducts. Since no defect in tubular sodium transport has been found in sickle cell patients, a limitation in maintaining a high concentration of solute in the medullary interstitium appears to be of primary importance in the mechanism responsible for the $\mathrm{T}^{\mathrm{c}} \mathrm{H}_{20} \mathrm{O}$ : Cosm curves during hypertonic saline diure- 
sis as well as the concentrating defect in sickle cell anemia.

The reason for this limitation on medullary solute concentration must remain speculative at this time. Indirect evidence suggests a possible increase, rather than a decrease, in medullary blood flow, which has been shown to produce a loss in renal concentrating ability, presumably through a decrease in medullary solute concentration (27). Large juxtamedullary glomeruli with dilatation of both the afferent and efferent arterioles have been described in the kidneys of children with sickle cell anemia $(3,28)$. Furthermore, Etteldorf, Smith, Tuttle, and Diggs have shown that both the ratios of effective renal plasma flow/maximal transport of $p$-aminohippurate $\left(\mathrm{Tm}_{\mathrm{PAH}}\right)$ and of effective renal blood flow/ $\mathrm{Tm}_{\mathbf{P A H}}$ as measurements of tubular purfusion by plasma are supranormal in children with sickle cell anemia, indicating increased vascularity or vasodilatation or both (7). Recent hemodynamic evidence from our laboratory, showing the extraction of PAH to be normal or decreased and the noncortical plasma flow to be normal or increased in young sickle cell patients, offers additional support to the concept of increased medullary blood flow (29).

A second factor that probably influences medullary solute accumulation pertains to the vascular changes that begin in early childhood. The medullary capillaries become dilated and tortuous (3), and their spatial configuration becomes anatomically distorted. The effect of these changes on renal concentration may result in a less efficient countercurrent exchange system, which could then fail to prevent solute loss from the medullary interstitium. These changes advance with age and become increasingly important in the early decline of renal function.

\section{Acknowledgments}

We wish to express our appreciation to Dr. Silvia Azar for valuable technical assistance; to Marion McDaniel, Charlene Stamper, and Colette Trapp for the laboratory analyses; and to Dr. Daniel Brody for his helpful advice in statistical testing.

\section{References}

1. Whitten, C. F., and A. A. Younes. A comparative study of renal concentrating ability in children with sickle cell anemia and in normal children. J. Lab. clin. Med, 1950, 55, 400 ,
2. Heinemann, H. O., and M. W. Cheung. Renal concentrating mechanism in sickle-cell anemia. J. Lab. clin. Med. 1957, 49, 923.

3. Bernstein, J., and C. F. Whitten. A histologic appraisal of the kidney in sickle cell anemia. Arch. Path. 1960, 70, 407.

4. Mostofi, F. K., C. F. Vorder Bruegge, and L. W. Diggs. Lesions in kidneys removed for unilateral hematuria in sickle-cell disease. Arch. Path. 1957, 63, 336.

5. Tellem, M., A. I. Rubenstone, and A. M. Frumin. Renal failure and other unusual manifestations in sickle-cell trait. Arch. Path. 1957, 63, 508.

6. Schlitt, L., and H. G. Keitel. Pathogenesis of hyposthenuria in persons with sickle cell anemia or the sickle cell trait. Pediatrics 1960, 26, 249.

7. Etteldorf, J. N., J. D. Smith, A. H. Tuttle, and L. W. Diggs. Renal hemodynamic studies in adults with sickle cell anemia. Amer. J. Med. 1955, 18, 243.

8. Mason, V. R. Sickle cell anemia. J. Amer. med. Ass. 1922, 79, 1318.

9. Lucas, W. M., and W. H. Bullock. Hematuria in sickle cell disease. J. Urol. (Baltimore) 1960, 83, 733.

10. Allen, T. D. Sickle cell disease and hematuria: a report of 29 cases. J. Urol. (Baltimore) 1964, 91, 177.

11. Walser, M., D. G. Davidson, and J. Orloff. The renal clearance of alkali-stable inulin. J. clin. Invest. $1955,34,1520$.

12. Dixon, W. J., and F. J. Massey, Jr. Introduction to Statistical Analysis, 2nd ed. New York, McGrawHill, 1957.

13. Zak, G. A., C. Brun, and H. W. Smith. The mechanism of formation of osmotically concentrated urine during the antidiuretic state. J. clin. Invest. 1954, 33, 1064.

14. Windhager, E. E., and G. Giebisch. Micropuncture study of renal tubular transfer of sodium chloride in the rat. Amer. J. Physiol. 1961, 200, 581.

15. Goldberg, M., D. K. McCurdy, and M. A. Ramirez. Differences between saline and mannitol diuresis in hydropenic man. J. clin. Invest. 1965, 44, 182.

16. Giebisch, G., R. M. Klose, and E. E. Windhager. Micropuncture study of hypertonic sodium chloride loading in the rat. Amer. J. Physiol. 1964, 206, 687.

17. Lassiter, W. E., M. Mylle, and C. W. Gottschalk. Net transtubular movement of water and urea in saline diuresis. Amer. J. Physiol. 1964, 206, 669.

18. Levitt, M. F., A. D. Hauser, M. S. Levy, and D. Polimeros. The renal concentrating defect in sickle cell disease. Amer. J. Med. 1960, 29, 611.

19. Hatch, F. E., and L. W. Diggs. Fluid balance in sickle-cell disease. Arch. intern. Med. 1965, 116, 10.

20. Keitel, H. G. Water metabolism in sickle-cell anemia (abstract). Amer. J. Dis. Child. 1957, 94, 549. 
21. Gottschalk, C. W. Micropuncture studies of tubular function in the mammalian kidney. Physiologist 1961, 4, 35 .

22. Berliner, R. W., and D. G. I)avidson. Production of hypertonic urine in the absence of pituitary antidiuretic hormone. J. clin. Invest. 1957, 36, 1416.

23. Gottschalk, C. W., and M. Mylle. Micropuncture study of the mammalian urinary concentrating mechanism: evidence for the countercurrent hypothesis. Amer. J. Physiol. 1959, 196, 927.

24. Perillie, P. E., and F. H. Epstein. Sickling phenomenon produced by hypertonic solutions: a possible explanation for the hyposthenuria of sicklemia. J. clin. Invest. 1963, 42, 570.
25. Keitel, H. G., D. Thompson, and H. A. Itano. Hyposthenuria in sickle cell anemia: a reversible renal defect. J. clin. Invest. 1956, 35, 998.

26. Gottschalk, C. W. Osmotic concentration and dilution of the urine. Amer. J. Med. 1964, 36, 670.

27. Thurau, K., and P. Deetjen (with a report by $H$. Günzler). Die Diurese bei arteriellen Drucksteigerungen. Pflügers Arch. ges. Physiol. 1962, 274, 567.

28. Sydenstricked, V. P., W. A. Mulherin, and R. W. Houseal. Sickle cell anemia: report of two cases in children, with necropsy in one case. Amer. J. Dis. Child. 1923, 26, 132.

29. Hatch, F. E., S. H. Azar, and T. E. Ainsworth. Unpublished observations. 